\title{
PLANTS
}

\section{THE ST. LAZARE AREA OF MANITOBA: A BIODIVERSITY HOTSPOT}

CARY HAMEL, Manitoba Conservation Data Centre, Winnipeg, MB and ELIZABETH REIMER, University of Saskatchewan, Saskatoon, SK

\section{Introduction}

The area between St. Lazare, Manitoba and the Saskatchewan border represents one of Manitoba's largest intact native prairie landscapes. The uplands and river valleys in this region in turn support a number of species that are considered provincially rare in Manitoba. While White and Johnson (1980) reported seven provincially rare plant species from St. Lazare, current information is unavailable because few recent botanical surveys have focussed on this area. ${ }^{9}$ In 2002 , staff of the Manitoba Conservation Data Centre (CDC) attempted to update rare plant

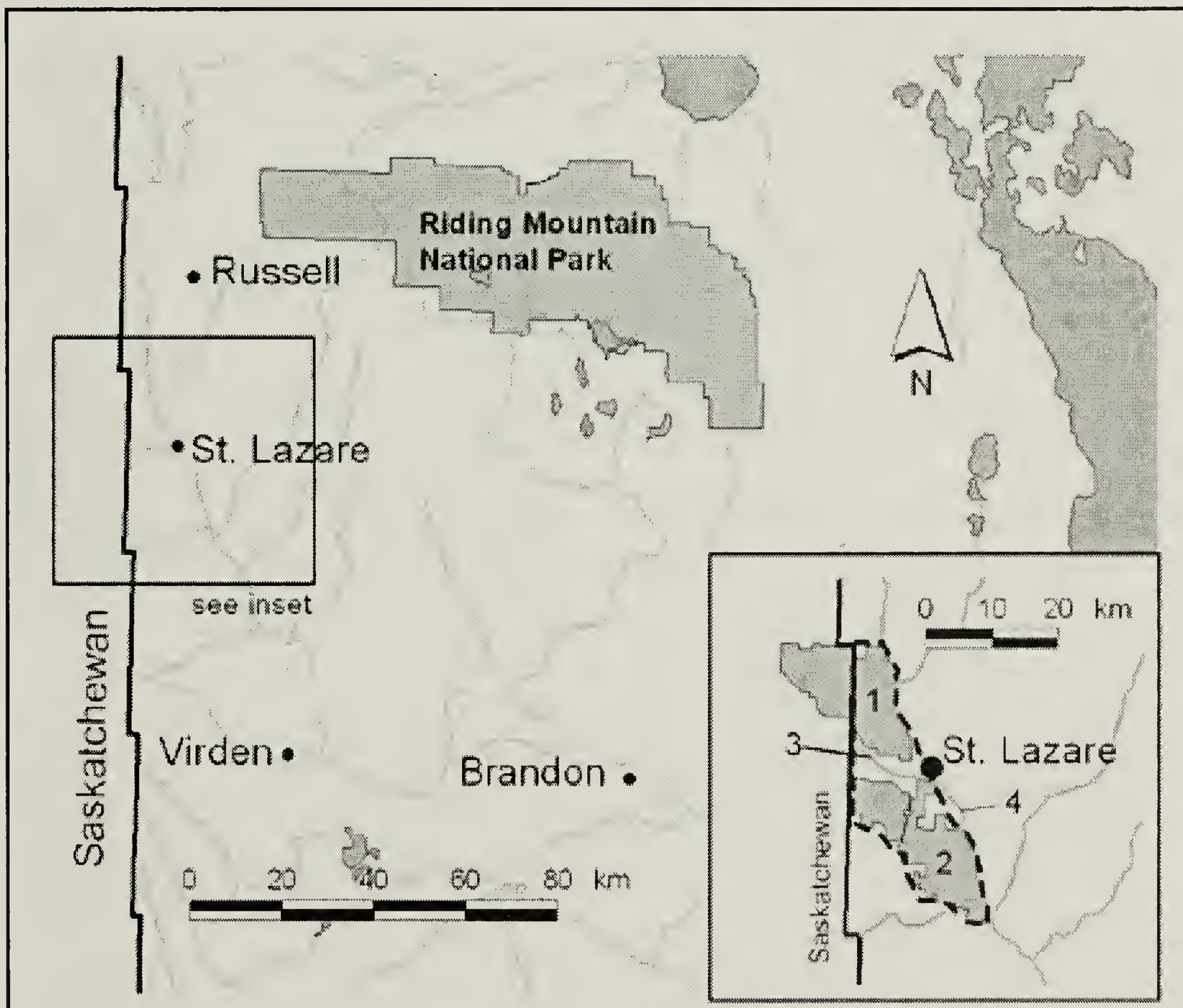

Figure 1. A portion of southwestern Manitoba showing the location of St. Lazare. Within the inset image, 'I' corresponds to the Spy Hill-Ellice Community Pasture, '2' to the Ellice-Archie Community Pasture, '3' to the Qu'appelle River, and '4' to the Assiniboine River. The approximate bounds of the study area are indicated by the dashed line. 
records from St. Lazare, and search for new occurrences of rare flora and rare grassland birds encountered incidentally. Comprehensive, up-to-date information is critical to assessing the status of rare species and identifying population trends and possible threats to these species and their habitats. Effective landscape-scale conservation planning and conservationminded land management also hinge on the quality of available biodiversity data.

\section{Methods}

Site description

The study focussed on upland native habitat northwest and southwest of St. Lazare, Manitoba, as well as within the Qu'Appelle River Valley immediately west of the town (Figure 1). The study area is bounded on the west by the Manitoba/ Saskatchewan border and on the east by the Assiniboine River. The Qu'Appelle River runs through the middle from west to east. The study area is an example of a grassland community within the Aspen Parkland ecoregion.

The south side of the Qu'Appelle River Valley, near the town of St. Lazare, is dominated by Aspen (Populus tremuloides) woodland, but the north side is characterised by grassland. Deltaic sand deposits mark its junction with the Assiniboine River. In places this sand has been reworked by wind into dunes that have since become partially to fully vegetated. Large Prairie Farm Rehabilitation Administration (PFRA) community pastures dominate the uplands on both sides of the Qu'Appelle River Valley, with Ellice-Archie $\left(152.6 \mathrm{~km}^{2}\right)$ to the south and the border-straddling Spy Hill-Ellice $\left(159.7 \mathrm{~km}^{2}, 84 \mathrm{~km}^{2}\right.$ of which is within Manitoba) to the north. The pastures are flat, open grasslands with occasional stands of Aspen. Creeks and gullies wind through the area, and these are often lined with trees such as Paper Birch (Betula papyrifera), Bur Oak (Quercus macrocarpa), Balsam Poplar (Populus balsamifera) and Aspen.
Soils in the community pastures are mostly of the Marringhurst association, characterised by sandy loam, with moderate to excessive drainage. ${ }^{2}$ These soils are susceptible to drought and wind erosion. Typical vegetation on this soil association includes Blue Grama (Bouteloua gracilis), Porcupine Grass (Hesperostipa spartea), June Grass (Koeleria macrantha), Spear Grass (Hesperostipa spartea), Prairie Sagewort (Artemisia ludoviciana), Low Goldenrod (Solidago missouriensis), Creeping Juniper (Juniperus horizontalis), and Three-flowered Avens (Geum triflorum). ${ }^{6}$

The two community pastures, and the Qu'Appelle River Valley between them, represent an island of native habitat within an area largely converted to cultivation (Figure 2).

\section{Survey methodology}

Surveys concentrated on four distinct habitats: the sandhill area within the Qu' Appelle River Valley near its confluence with the Assiniboine River; the untreed prairie on the south-facing slope of the Qu'Appelle River Valley; the open sandy prairie dominating the uplands immediately north and south of the valley; and freshwater springs on the upper slopes of the Assiniboine and Qu' Appelle Rivers and their tributaries.

The authors conducted surveys on May 27 to 28 , June 17 to 20 , and August 12 to 13 , 2002. Study sites were accessed by truck or on foot. The locations of rare species and other organisms of interest were recorded with a Garmin GPS unit. Additional information recorded at each site included patch size, abundance, habitat, associated species, slope, aspect, and condition. Where populations were sufficiently large, voucher specimens of selected species were collected and deposited in the University of Manitoba Herbarium (WIN). Plant scientific nomenclature follows Kartesz. ${ }^{5}$ 


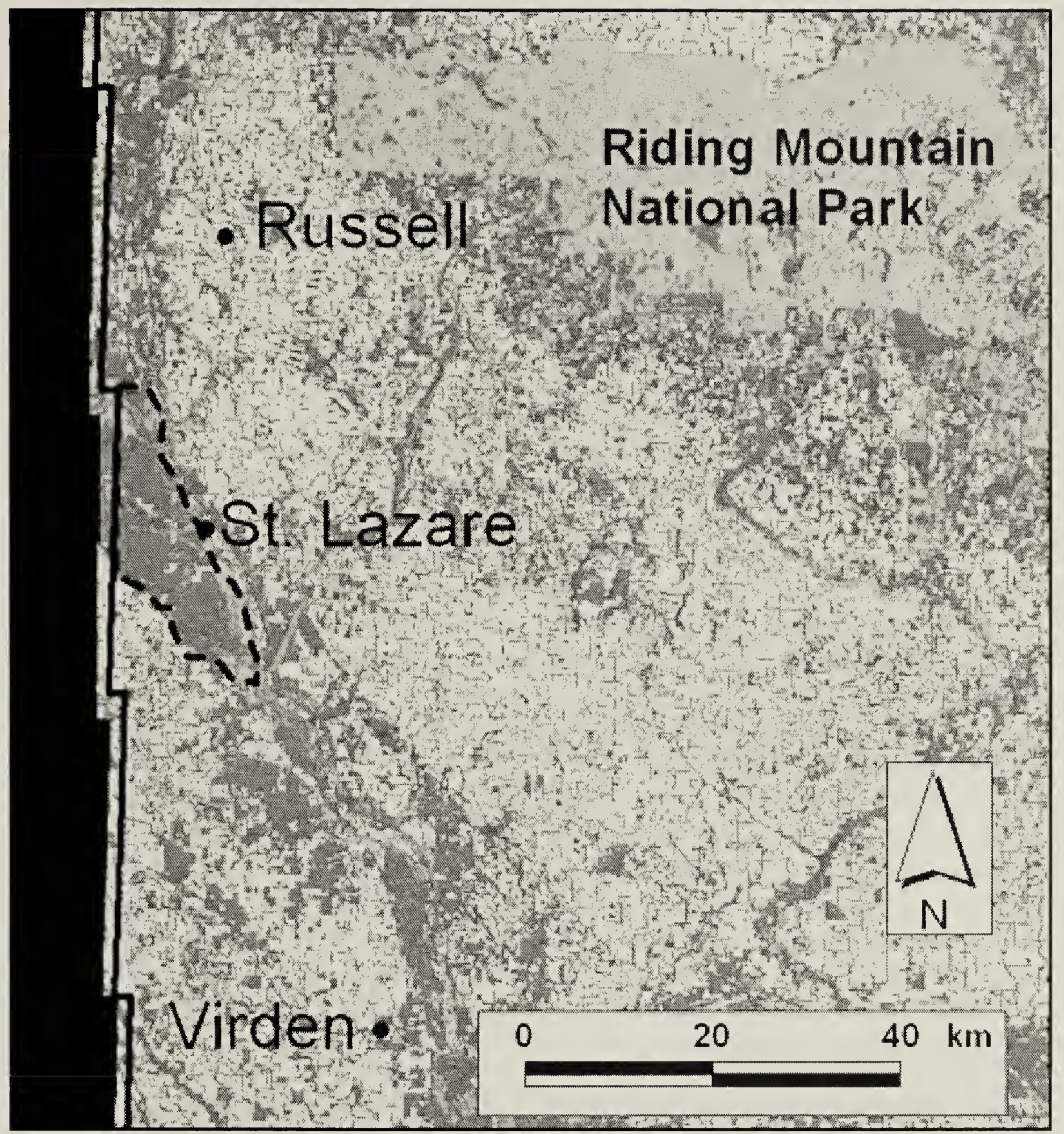

Figure 2. A Landsat satellite image of a portion of southwestern Manitoba. Shading represents the differing reflectance of various habitat types. Light shading represents cultivated lands, whereas darker shading indicates grassland, forest, or water. Darkly shaded areas in and around Riding Mountain National Park and in river valleys are largely forest; other darkly shaded areas are largely grassland. The grasslands and forested areas near St. Lazare represent an island of native habitat within a region dominated by cultivated lands. The approximate bounds of the study area are indicated by the dashed line.

Observations of Sprague's Pipit were recorded on an opportunistic basis. Song and behaviour were used to identify this species, a standard identification practice for this cryptic bird (Ken De Smet, Manitoba Conservation, pers. comm.). All occurrences of rare organisms were mapped in the
Manitoba CDC database using the Biotics 3.1 GIS application.

\section{Results}

Four rare species (Low Townsendia (Townsendia exscapa), Indian Rice Grass (Achnatherum hymenoides), Waxleaf 
Beardtongue (Penstemon nitidus) and Sand Bluestem (Andropogon hallii)) were found in the sand deposits at the junction of the Qu'Appelle and Assiniboine Rivers. This community was dominated by Plains Wormwood (Artemisia campestris), Sand Grass (Calamovilfa longifolia), Sand Dropseed (Sporobolus cryptandrus), Holboell's Rock-cress (Arabis holboellii), and Creeping Juniper. Smooth Brome (Bromus inermis) and Alfalfa (Medicago sativa) dominated roadsides at this site. Open sand at a sand extraction site supported Waxleaf Beardtongue and Sandmat (Chamaesyce serpyllifolia).

One rare species (Sand Bluestem) and one uncommon species (Yellow Umbrella-plant (Eriogonum flavum)) were observed in grasslands on the south-facing valley slope above the Qu'Appelle River. Sand Bluestem and Sand Grass dominated these sites. In contrast, other portions of the south-facing slope were characterised by woodland species, especially Bur Oak, Chokecherry (Prunus virginiana), Aspen, and False Solomon's-seal (Maianthemum stellatum).

Four rare species (Waxleaf Beardtongue, Slender Beardtongue (Penstemon procerus),
Early Yellow Locoweed (Oxytropis sericea) and Sprague's Pipit) and two uncommon species (Large-fruited Parsley (Lomatium macrocarpum) and Moss Pink (Phlox hoodii)) occurred in the open sandy prairie of the uplands. This community was dominated by Creeping Juniper, Big Bluestem (Andropogon gerardii), Little Bluestem (Schizachyrium scoparium), Blue Grama, Stipa species, bare sandy soil, and mosses and lichens. Aspen copses were occasional.

One rare species (Roundleaf Monkeyflower (Mimulus glabratus)) was observed in freshwater springs. Vegetation around springs was normally characterised by a canopy of Balsam Poplar and other deciduous trees, a dense shrub canopy, and a mossy understory through which cold spring water flowed.

\section{Rare and Uncommon Species}

Surveyors recorded 40 occurrences of eleven provincially rare or uncommon species (Table 1). These species can be sorted into two groups. The first, comprised of western grassland species that reach the northeastern limit of their range in southwestern Manitoba, are considered

Table 1. Rare and uncommon species encountered in the St. Lazare area. More details about each species can be found in the text.

\begin{tabular}{llccc}
\hline Latin Name & Common Name & G Rank* & N Rank* & S Rank* \\
\hline Achnatherum hymenoides & Indian Rice Grass & G5 & NNR & S2 \\
Andropogon hallii & Sand Bluestem & G4 & N1 & S2 \\
Anthus spragueii & Sprague's Pipit & G4 & N4 & S2S3B \\
Eriogonum flavum & Yellow Umbrella-plant & G5 & N5 & S3 \\
Lomatium macrocarpum & Large-fruited Parsley & G5 & NNR & S3? \\
Mimulus glabratus & Roundleaf Monkey-flower & G5 & N2 & S1 \\
Oxytropis sericea & Early Yellow Locoweed & G5 & NNR & S1 \\
Penstemon nitidus & Waxleaf Beardtongue & G5 & NNR & S2 \\
Penstemon procerus & Slender Beardtongue & G5 & NNR & S1S2 \\
Phlox hoodii & Moss Pink & G5 & NNR & S3S4 \\
Townsendia exscapa & Low Townsendia & G5 & NNR & S2 \\
\hline *G Rank = Global Conservation Status Rank, N Rank= National Conservation Status Rank, S Rank= Subnational (Manitoba) \\
Conservation Status Rank. Ranks roughly correspond to: 1=very rare, 2=rare, 3=unconmon, 4=apparently secure, 5=secure. NR=not \\
ranked, B=breeding. Full definitions can be viewed at http://web2.gov.mb.ca/conservation/cdc/info.php \\
\end{tabular}


provincially rare in Manitoba but are common in the heart of their range to the west and south. One of these species, Early Yellow Locoweed, is known in Manitoba only from the St. Lazare area. The second group consists of species considered rare across Canada, as well as in Manitoba.

Group 1: Prairie species reaching the edge of their range in southwestern Manitoba

Early Yellow Locoweed was found on open prairie in May and June in upland areas both north and south of the Qu'Appelle River Valley. It was easiest to identify in May when the showy light yellow flowers were evident and the stems of the surrounding grasses were not elongated. CDC surveys in 2002 confirmed the continued presence of the species in Manitoba; the species was first recorded near St. Lazare by Macoun \& Herriot in $1906 .{ }^{8}$ This species is at the northeastern limit of its range in Manitoba but is considered secure in Saskatchewan.

Low Townsendia was found at 2 locations, both within the Qu'Appelle River Valley on sparsely vegetated sandhills. This species is also known from other sandhill areas in southwestern Manitoba.

Indian Rice Grass was found in open sand near the confluence of the Qu'Appelle and Assiniboine Rivers. It is also known from other sandhill areas in southwestern Manitoba.

Waxleaf Beardtongue was observed flowering in June at three prairie areas of the Qu'Appelle River Valley and the uplands north of the river (Figure 3). Outside of the St. Lazare area, this species has been recorded at only two other Manitoba locations.

Slender Beardtongue was observed in midJune at five locations in the uplands south of the Qu'Appelle River. The CDC database contains records for previous collections from near Pierson, Virden, Miniota and Reston, but none more recent than 1950.

Large-fruited Parsley was observed flowering in May and fruiting in June. CDC surveys located two occurrences in the uplands south of the Qu'Appelle River

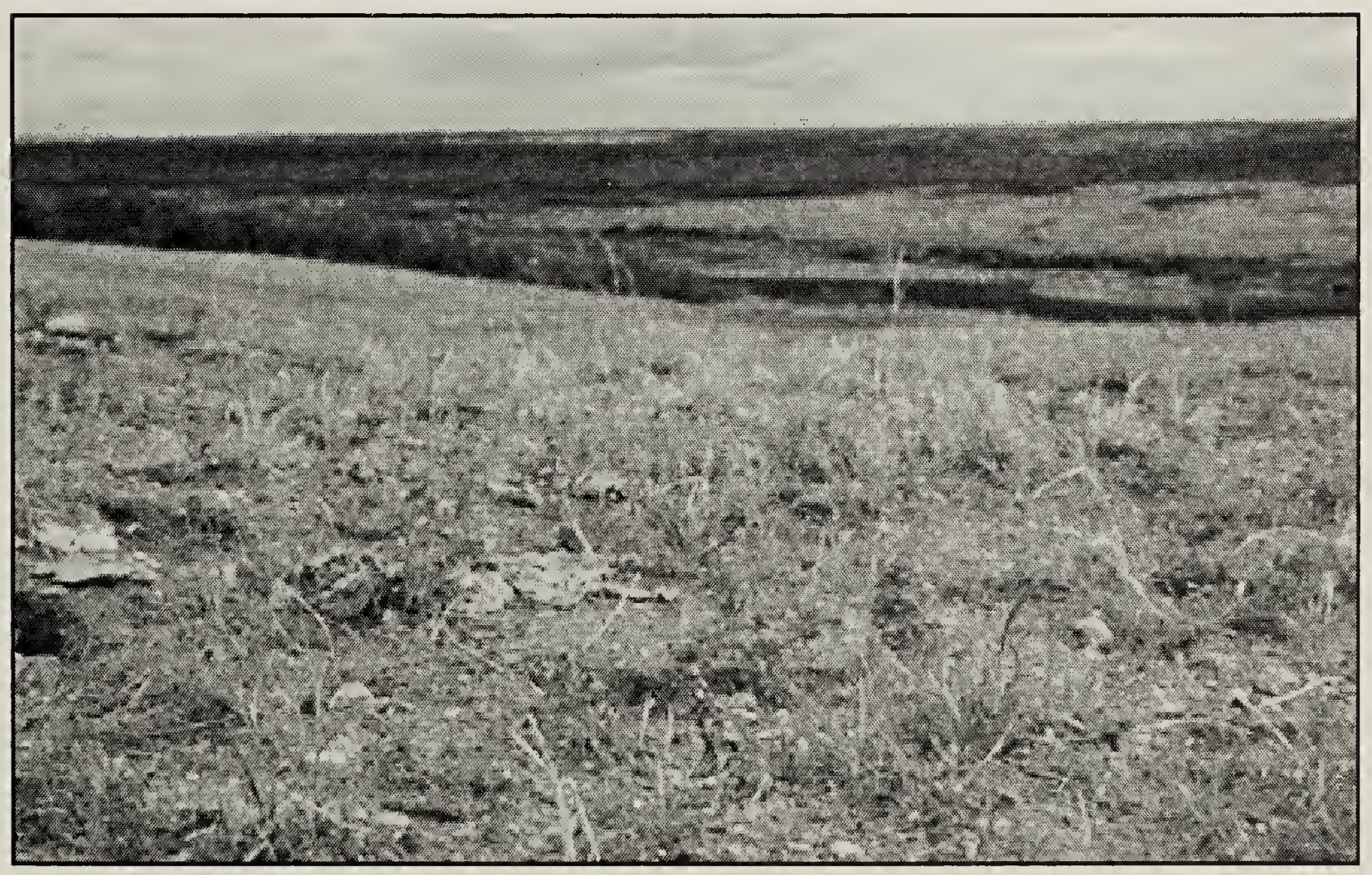

Figure 3. Waxleaf Beardtongue in upland habitat north of the Qu'appelle River Valley. The Valley can be seen in the background. 


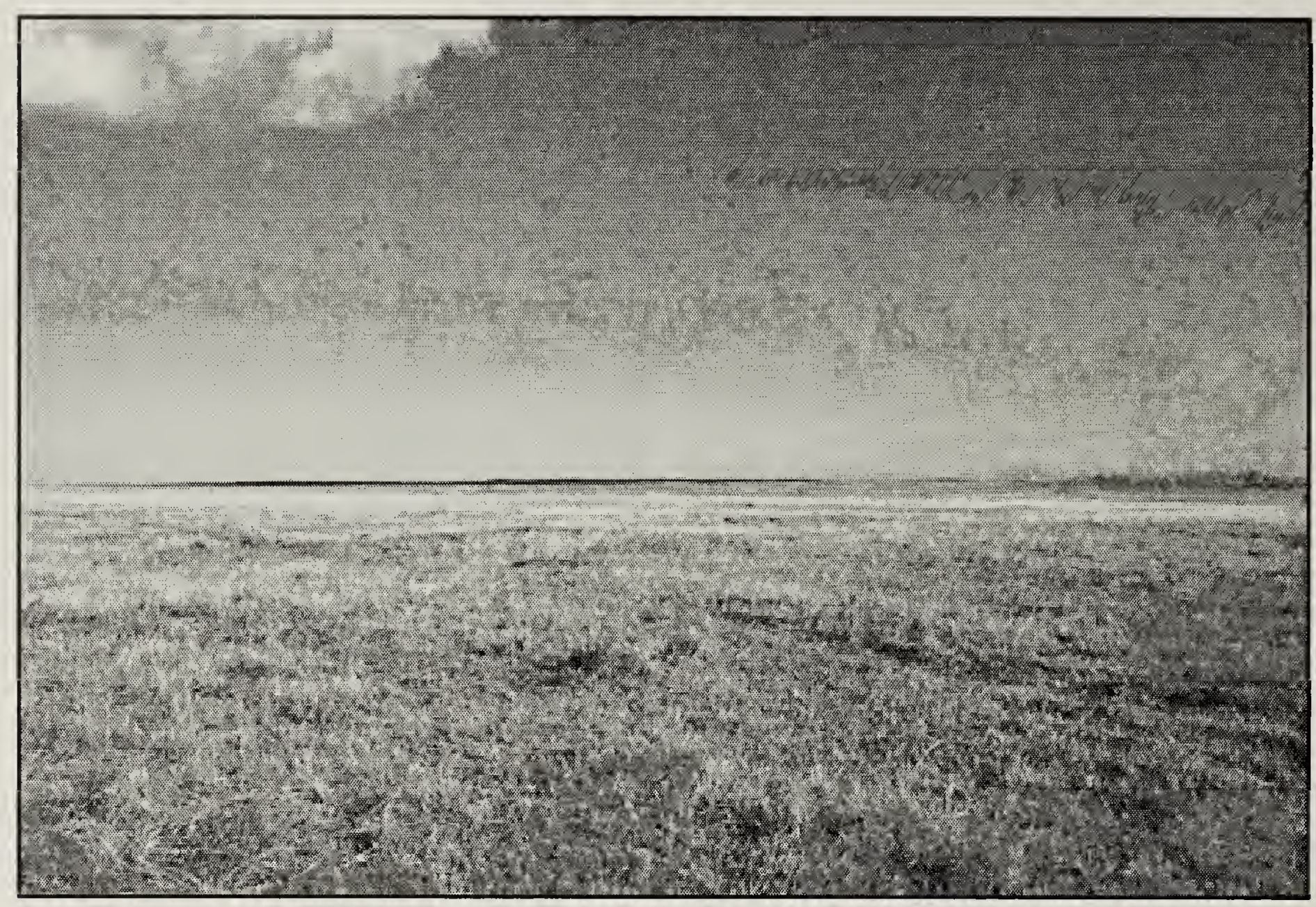

Figure 4. Large-fruited Parsley habitat in the uplands southwest of St. Lazare.

(Figure 4). This species is known from a number of widely separated locations in south-central and southwestern Manitoba.

Yellow Umbrella-plant was observed at a single location in prairie on the south-facing slope of the Qu'Appelle River Valley west of St. Lazare. This provincially uncommon species is also known from a number of other locations in southwest Manitoba.

Moss Pink was observed twice, at the top of a slope overlooking the Assiniboine River and on a gentle slope within open prairie. The provincial conservation status of Moss Pink is uncertain; it has been assigned a conservation rank of S3S4 (uncommon to apparently secure). The species occurs in dry prairies in southwestern Manitoba.

Group 2: Nationally rare species

Roundleaf Monkey-flower was found in August in springs and seepy slopes at three locations. This species is a freshwater springobligate and is rare in every Canadian province where it occurs. The Manitoba
Endangered Species Advisory Committee recommended a status of Threatened for Roundleaf Monkey-flower in February 2003. The status of Roundleaf Monkeyflower in Manitoba and its presence in the St. Lazare area have been previously documented in Blue Jay. ${ }^{3.4}$

Sand Bluestem was observed only in the sandhills that occur near the confluence of the Qu'Appelle and Assiniboine rivers, and on the south-facing slope of the Qu'Appelle River Valley. The species is a relatively common member of the flora of sandhill areas in southwestern Manitoba.

Sprague's Pipits were observed in the open prairies of uplands both north and south of the Qu'Appelle River Valley. Listening stops made in appropriate habitat revealed pipits at $72 \%$ of stops ( $n=19$ observations). This species is protected under Canada's Endangered Species Act as a Threatened species.

\section{Discussion}

With its abundance of native grassland 
and associated habitats, and concentration of provincially and nationally rare species (Figure 5), the St. Lazare area represents an excellent opportunity for conservation. In 1987, Rowe estimated that $80 \%$ of the Aspen Parkland was under cultivation, with most remnants fragmented into patches less than 1000 hectares in size. ${ }^{7}$ Cultivation
The PFRA has been managing the Spy Hill-Ellice Community Pasture since 1941, and the Ellice-Archie Community Pasture since 1940. Management strategies in the community pastures include grazing and controlled burns (John Istace, PFRA, pers. comm.). Most rare prairie plants in the community pastures are adapted to both

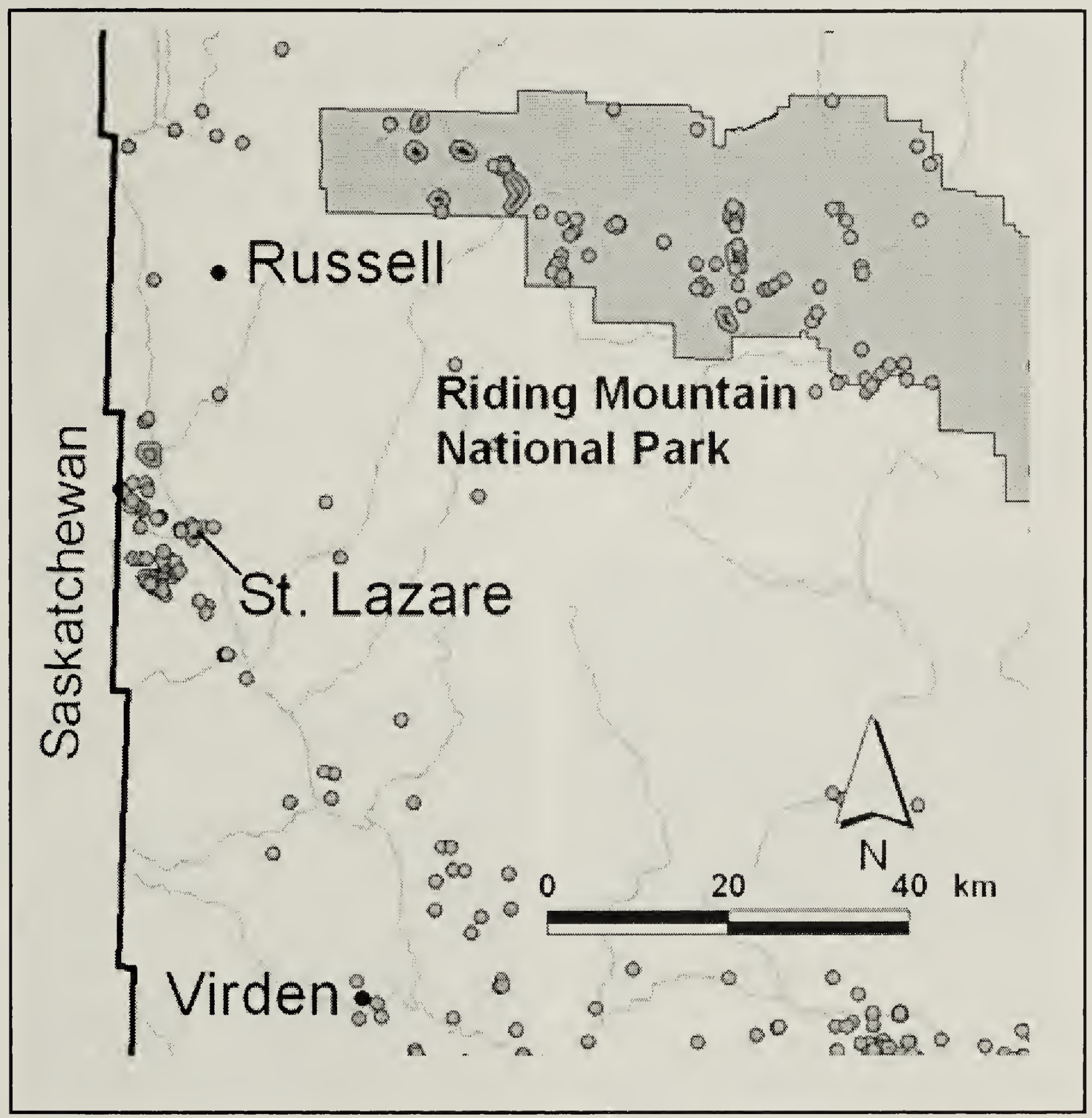

Figure 5. Provincially rare and uncommon species occurrences (dark circles and polygons) in west-central Manitoba, as recorded in the Manitoba Conservation Data Centre database. Occurrences are concentrated in the St. Lazare area.

continues to be a threat to the prairies, with 4.7 million hectares of marginal land cultivated annually. ${ }^{\prime}$ Other threats to the region include resource extraction, especially sand and gravel, potash, and petroleum. burning and grazing, and have an excellent chance of persisting under the current management strategy.

Surveyed areas of the Qu'Appelle River Valley's south-facing slope appear to be only 
lightly grazed and exhibit little evidence of disturbance. As some aspen encroachment was observed, consideration of the use of prescribed fire may be warranted.

Freshwater springs containing Roundleaf Monkey-flower were accessible to livestock and extensive trampling of spring vegetation was observed at one location. The installation of fencing and an off-site watering system would likely reduce the impact of livestock on spring communities.

The sandhills near the confluence of the Assiniboine and Qu'Appelle Rivers support a unique assemblage of provincially rare species. Portions of this area are used for sand extraction, and ATV tracks indicate that this area is also used for recreation. Further protection of this area, through conservationminded management and/or conservation easements, would help ensure the long-term suitability of rare species habitat.

The concentration of rare and uncommon species in the St. Lazare area is indicative of a large, intact and connected landscape that is being managed in a manner that promotes the maintenance of biodiversity. The contribution of the area to Manitoba's overall biological diversity is significant, and warrants the reinforcement and expansion of current habitat stewardship activities.

\section{Acknowledgements}

This research was made possible through the support of the Habitat Stewardship Program, the Manitoba Special Conservation Fund, the Canadian Wildlife Service, Environment Canada, Manitoba Conservation, and the Manitoba Habitat Heritage Corporation. PFRA staff, including Blake Coutts, John Istace, and Wayne
Lenfesty, provided access permission and valuable survey advice. Catherine Foster and Jason Greenall of the Manitoba CDC and Marilena Kowalchuk of Manitoba's Mixed Grass Prairie Inventory made valuable editorial suggestions, as did an anonymous reviewer.

1. AGRICULTURE AND AGRI-FOOD CANADA. 1997. Biodiversity in Agriculture: Agriculture and Agri-food Canada's Action Plan. Agriculture and Agri-food Canada. Ottawa, ON

2. EHRLICH, W.A., L.E. PRATT, and E.A. POYSER. 1956. Report of Reconnaissance Soil Survey of Rossburn and Virden Map Sheet Areas. Manitoba Soil Survey Report No. 6. Manitoba Department of Agriculture, Winnipeg, MB

3. HAMEL, C., K. DE SMET, and E. REIMER. 2002. New Roundleaf monkey-flower (Mimulus glabratus) occurrences in Manitoba. Blue Jay 60(2):83-87.

4. HAMEL, C. and E. REIMER. 2002. Additional Roundleaf monkey-flower populations in Manitoba. Blue Jay 60(4):224-225.

5. KARTESZ, J.T. 1999. A Synonymized Checklist and Atlas with Biological Attributes for the Vascular Flora of the United States, Canada, and Greenland. First Edition. In: Kartesz, J.T. and C.A. Meacham. Synthesis of the North American Flora, Version 1.0. North Carolina Botanical Garden, Chapel Hill, NC

6. MANSELL, T. and J. MOORE. 1999. Mixed-grass Prairie Inventory. Interim Status Report. Manitoba Natural Resources. Winnipeg, MB

7. ROWE, S. J. 1987. Status of the Aspen Parkland in the Prairie Provinces. pp. 27-33 In: Holroyd, Geoffrey, W. Bruce McGillivray, Philip H. R. Stepney, David M. Ealey, Garry C. Trottier, and Kevin E. Eberhart (eds.) Endangered Species in the Prairie Provinces. Natural History Occasional Paper No. 9. Provincial Museum of Alberta, Edmonton, AB

8. SCOGGAN, H.J. 1957. Flora of Manitoba. Bull. 140, Biological Series 47, National Museum of Canada, Ottawa, ON

9. WHITE, D.J., and K.L. JOHNSON. 1980. Rare Vascular Plants of Manitoba. National Museums of Canada Syllogeus No. 27, Ottawa, ON

Folk names for Sprague's Pipit are "Sky-jingler, skylark (It sings on the wing)"

W. L. McAtee, Folk names of Canadian Birds, p. 56 